TITLE:

\title{
Is driving a car a risk for
}

Legionnaires' disease?(Abstract_要 旨)

$\operatorname{AUTHOR}(S)$ :

Sakamoto, Ryota

CITATION:

Sakamoto, Ryota. Is driving a car a risk for Legionnaires' disease?. 京都 大学, 2009, 博士(医学)

ISSUE DATE:

2009-09-24

URL:

http://hdl.handle.net/2433/126450

RIGHT: 


\begin{tabular}{|l|l|c|l|}
\hline 京都大学 & 博士 (医学) & 氏 名 & 坂本 龍太 \\
\hline 論文題目 & $\begin{array}{l}\text { Is driving a car a risk for Legionnaires’ disease? } \\
\text { (自動車の運転はレジオネラ症の危険因子か) }\end{array}$ \\
\hline
\end{tabular}

(論文内容の要旨)

レジオネラ症は、市中肺炎の 2 2 $15 \%$ を占めるとされ、なかでも重症市中肺炎では 3 大起 因菌の一つともいわれる。2005 年 10 月日本呼吸器学会は成人市中肺炎診療ガイドライン を発行し入院を要する成人市中肺炎患者全例にレジオネラ尿中抗原検査を奨励し、その 後、日本におけるレジオネラ症報告数は著明に増加しているが、未報告例や見逃されてい る症例がまだまだ多いと推測されている。感染源について、冷却塔、給水システム、温泉、 シャワー、加湿器、人工呼吸器、などの報告がみられるが、特に孤発症例において、原因 不明なものが多い。本研究は、レジオネラ症を発症したトラック運転手の自動車空調設備 からレジオネラ属菌が検出されたことに端を発した。Boerらの行った前向き症例対照研究 から、レジオネラ症の孤発症例がプロの運転手で約 3 倍多い傾向があった、と報告されて いるが、その機序は不明であった。本研究の目的は、レジオネラ症が自動車空調設備から 感染する可能性を探ることであった。方法として、2006 年 10 月に自動車リサイクル工場 により廃品回収された自動車からエバポレーターという空調部品が取り出され、そのアル ミニウム熱交換フィンが綿棒で拭い液が採取された。その検体からレジオネラ属菌を検出 するために、標的遺伝子の 6 つの領域に対して 4 種類のプライマーを設定し鎖置換反応を 利用して一定温度で反応させることを特徵とする Loop-mediated isothermal amplification (LAMP) 法という方法が用いられた。その結果、22 台中 11 台からレジオ ネラ属菌が検出された。また、2006 年 4 月から 2007 年 3 月までの間に国立感染症研究 所感染症情報センターに集められた全国のレジオネラ症報告症例のうち記載された職業 が分類可能であった 189 例を対象に職業構造を分析したところ、建設業及び運輸業が多い 可能性が示唆された。さらに、主に運送業者に勤務する健康診查受診男性 152 名を対象に、 喫煙などのレジオネラ症の危険因子や自動車空調設備の使用状況などに関するアンケー 卜調査が行われるとともに、血液検体が採取され、マイクロプレート凝集法を用いて血清 抗体価が調べられた。その結果、自動車空調設備を「時々使用する」と回答した群におい て、それ以外の自動車空調設備使用状況の群に比べ、Legionella pneumophila 血清型 1 ～6 血清に対する抗体価が 32 倍以上となる例が有意に多かった。本研究により、自動車 の空調設備中にレジオネラ属菌の遺伝子が散在することが証明され、レジオネラ症の潜在 的な危険因子となる可能性が残された。Kumar らは自動車空調設備の湿気により微生物 がバイオフィルムを形成するのに適した環境が備わりうることを指摘している。レジオネ ラ属菌が自動車エバポレーターから検出されたといら報告はおそらく本研究が最初であ ろう。今回の研究では LAMP 法によって他の菌が混在する環境中からのレジオネラ属菌 の検出が可能となった。LAMP 法で陽性であってもその菌の生死は不明であり、この結 果からだけでは自動車の空調設備から検出されたレジオネラ属菌とレジオネラ症の直接 の関係が証明されていないが、自動車を利用する人間一の影響を考慮し、今後さらに詳し く調査する必要性が示唆された。レジオネラ属菌は日常生活環境中に散在する、という認 識が重要である。
（論文審査の結果の要旨）

日本におけるレジオネラ症報告数は著明に増加しているが、未報告例や見逃されている 症例も多いと推測されている。感染源については、冷却塔、給水システム、温泉、シャ ワー、加湿器、人工呼吸器などの報告がみられるが、特に孤発症例において原因不明な ものが多い。本研究では、自動車リサイクル工揚により廃品回収された自動車 22 台中 11 台のエバポレーターからLoop-mediated isothermal amplification(LAMP)法により レジオネラ属菌が検出された。また、主に運送業に従事寸る健康診査受診男性 152 名を対 象とするマイクロプレート凝集法を用いたレジオネラ血清抗体価測定の結果では、自動 車空調設備を「時々使用寸る」と回答した群において、それ以外の群に比べ、Legionella pneumophil a 血清型1６血清に対寸る抗体価が32倍以上となる例が有意に多かった。 これらの結果からだけでは自動車の空調設備から検出されたレジオネラ属菌とレジオネ ラ症の直接の関係は証明されていないが、レジオネラ属菌が自動車エバポレーターから 検出された報告はおそらく本研究が最初であり、自動車の空調設備中にレジオネラ属菌 の遺伝子が散在することが証明され、レジオネラ症の潜在的な危険因子となる可能性が 指摘できる。以上の研究はレジオネラ症の発症機序の解明に貢献し、レジオネラ症の予 防対策の構築に寄与するところが多い。

したがって、本論文は博士(医学)の学位論文として価値あるものとみとめる。

なお、本学位授与申請者は、平成21年8月 24 日実施の論文内容とそれに関連した諮問を受 け、合格と認められたものである。 